\title{
TOXICOLOGICAL SUBSTANTIATION FOR DIDECYLDIMETHYLAMMONIUM CHLORIDE OCCUPATIONAL EXPOSURE STANDARD
}

\author{
P. Zhminko, V. Voronina, S. Svitlyi, L. Rudaia \\ L.I. Medved's Research Centre of Preventive Toxicology, Food and Chemical Safety, \\ Ministry of Health, Ukraine (State Enterprise), Kyiv, Ukraine
}

\begin{abstract}
Dydetsyldymetylammonium chloride (DDAC) is used as a raw material in the chemical industry for the production of some insecticidal, fungicidal and aldehydic preparations and disinfectants in which it is an active ingredient.

Aim of the Research. To establish a scientific substantiation for DDAC indicative safe exposure level (ISEL) in the workplace air by analyzing and summarizing the bibliographic data about the degree of DDAC danger.

Methods. To establish a scientific substantiation for DDAC occupational exposure standard the following properties were analyzed: its physical and chemical characteristics; $L D_{50}$ (lethal dose) for oral and dermal exposure; $L C_{50}$ (lethal concentration) for inhalation exposure; irritant and sensitizing properties; NOAELs (no-observed adverse effect level) for DDAC were determined in sub-acute and subchronic experiments under different conditions of exposure as well as its long-term effects.

The calculation of DDAC ISEL in the workplace air was performed using equations which make allowance for the toxicity properties of the preparation when it is administered to laboratory animals through different routes.

Results. DDAC is an imported product used as an active ingredient in the production of certain pesticides and disinfectants.

DDAC falls into the category of non-volatile substances: its vapor pressure is $<1 \times 10^{-2} \mathrm{~Pa}$ at $20^{\circ} \mathrm{C}$, at $50^{\circ} \mathrm{C}-2,3 \times 10^{-4} \mathrm{~Pa}$ (US ISC)

When introduced into the gastrointestinal tract, the substance is classified as moderately dangerous - Category 3 (in accordance with Globally Harmonized System of Classification and Labeling of Chemicals / GHS / United Nations, New York and Geneva, 2017) and has a mild skin-resorptive effect (Category 4, GHS). Its adverse local impact on the skin has been identified. The substance $L C_{50}$ after inhalation exposure is $70 \mathrm{mg} / \mathrm{m}^{3}$ (Category 2, GHS). DDAC produces marked irritant action on the skin and conjunctiva of rabbits $($ Category1B, GHS). Erythema, crust and swelling were recorded on skin. Burns, corrosion, acute keratoconjunctivitis were observed when the substance got onto conjunctiva. No sensitizing effect of the preparation was found (not classified, GHS). The cumulative properties of the substance are incomplete. NOAELs were determined in sub-acute and sub-chronic experiments after oral, dermal and inhalation exposure. The most affected organs and systems are skin, eyes, gastrointestinal tract, liver. Mutagenic, carcinogenic, embryotoxic, teratogenic and toxic effects on the reproductive function are not limiting harmful criteria.

Calculation of the value of DDAC ISEL in the workplace air was conducted by the equations of regressive dependence, which take into consideration the parameters of acute toxicity. Making allowance for the degree of its hazard and the risk of developing the pathology of general genesis under the effect of the substance, the recommended ISEL value in the workplace air is $0.2 \mathrm{mg} / \mathrm{m}^{3}$, aggregate state " $a$ " with the mark "protection of eyes and skin is necessary".
\end{abstract}

Key Words: dydetsyldymetylammonium chloride, DDAC, ISEL in the workplace air, insecticides, disinfectants.

Introduction. Measures to combat synanthropic insects and pathogenic microflora are aimed at ensuring sanitary and epidemiological welfare of the population and are essential means to maintain appropriate hygienic conditions in the areas of human activities. Therefore, it is of vital importance to study how to determine the degree of safety of disinfectants which are used for their designated purposes.

At present in Ukraine dydetsyldymetylammonium chloride (DDAC) is in use. This substance has a wide spectrum of action as well as selective biological activity in fighting synanthropic insects, phytopathogenic fungi, clams and virulent pathogens. DDAC is used as a raw material in the chemical industry for the production of insecticidal, aldehydic, bactericidal and fungicidal agents. It is used to control synanthropic insects in everyday life, to protect wood and products made of wood from insects and microorganisms. It is also used to protect crops from fungal diseases as well as to destroy algae and other weeds in water bodies. DDAC is also used as a substance having bactericidal and antiviral effect. Therefore, it is contained as an active ingredient in some disinfectants (microbiostates, viricides, tuberculocides, antiseptics and deodorants) which are used to treat various surfaces in different areas of human activity, such as walls, floors, dishes, rugs, medical devices, swimming pools etc.

In Ukraine, the substance is not produced, its occupational exposure standard is not developed. The urge to develop dydetsyldymetylamonium chloride ISEL in the air is due to the need to exercise control over its safe content in the workplace air while using pesticides and disinfectants developed on its base. 


\section{ORIGINAL RESEARCH}

TOXICOLOGY OF PESTICIDES

Calculations of the substance occupational exposure standard were performed on the basis of the data about DDAC toxicological properties acquired in the process of information retrieval using scholarly libraries abstract (reference) database.

The Aim of the Research. To analyze and summarize current data on the degree of DDAC danger while using it for its intended purpose; to provide a scientific basis for its ISEL in the workplace air.

Methods and Materials. Analytical review of scientific publications was performed using scholarly libraries abstract (reference) database and a text database of methodological and biological publications PubMed.

Results and Discussion. The information search of scientific publications made it possible to obtain information about DDAC physical-chemical and toxicological properties, on the basis of which calculations were made to determine its occupational exposure standard [1-22].

Physical-chemical parameters. DDAC belongs to quaternary ammonium compounds by its chemical structure $[1,2]$. Chemical name - N - didecyl - N, N-dimethylammonium chloride, empirical formula $\mathrm{C}_{22} \mathrm{H}_{48} \mathrm{Cl}$, structural formula

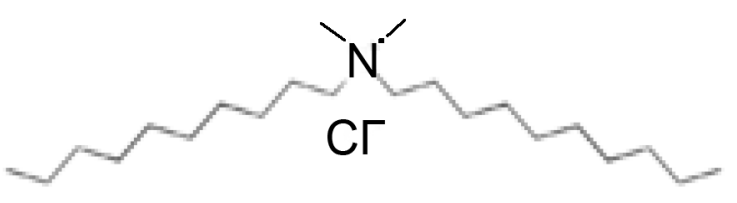

Abbreviation for didecyldimethylammonium chloride is DDAC. CAS RN 7173-51-5. Molecular weight is $362.08 \mathrm{~g} / \mathrm{mol}$. DDAC $98.2 \%$ is a light yellow solid substance with an aromatic odor. Relative density is $\mathrm{D}_{4}{ }^{20}-0,902$. Surface tension is $27.0 \mathrm{mN} / \mathrm{m}$ at $20^{\circ} \mathrm{C}$ (sample solution $1 \mathrm{~g} / 1$ of aqueous solution). Vapor pressure is $<1 \times 10^{-2} \mathrm{~Pa}$ at $20^{\circ} \mathrm{C}$, at $50^{\circ} \mathrm{C}-2.3 \times 10^{-4} \mathrm{~Pa}$. Volatility: extremely low. The octanol / water partition coefficient is $\log \mathrm{Kow}=0.41$ at $20^{\circ} \mathrm{C}$. Water solubility: $\mathrm{pH} 2.2-500 \mathrm{~g} / \mathrm{l}$ at $20^{\circ} \mathrm{C}$; $\mathrm{pH} 9,2-500 \mathrm{~g} / 1$ at $20^{\circ} \mathrm{C}$, in organic solvents (at $20^{\circ} \mathrm{C}$ ): acetone $>600 \mathrm{~g} / \mathrm{l}$; methanol $>600 \mathrm{~g} / \mathrm{l}$; octanol $>250 \mathrm{~g} / \mathrm{l}$.

Technical DDAC $(<80 \%)$ is a lightyellow liquid substance with a characteristic odor; $\mathrm{pH}$ at $25^{\circ} \mathrm{C}$ is $6.8-6.9$ (29.5\% aqueous solution). Density at $20^{\circ} \mathrm{C}$ is $0.95 \mathrm{~g} / \mathrm{cm}^{3}$. Solubility in water at $20^{\circ} \mathrm{C}$ is $650 \mathrm{~g} / \mathrm{l}$. Vapor pressure is 1.24
$10^{6} \mathrm{~mm} \mathrm{Hg}$ at $21.6^{\circ} \mathrm{C}$. Stable in organic solvents for 14 days.

Toxicological Properties. When administered through the gastrointestinal tract, DDAC belongs to moderately dangerous substances Category 3 (according to the Globally Harmonized System of Classification and Labeling of Chemicals / GHS / United Nations, New York and Geneva, 2017). LD 50 after oral exposure for rats is $84 \mathrm{mg} / \mathrm{kg}$ according to some data, and $238 \mathrm{mg} / \mathrm{kg}$ according to other data; for mice, it is $268 \mathrm{mg} / \mathrm{kg}$ [3, 2]. The symptoms of intoxication for rats and mice were similar: from a significant decrease in spontaneous motor activity to complete immobility. Macroscopic examination showed irritation of the intestinal mucosa. Species sensitivity is not significant.

DDAC (65\%) has a skin-resorptive effect. When applied epicutaneously its $\mathrm{LD}_{50}$ for rabbits is $3342 \mathrm{mg} / \mathrm{kg}$ (Category 4 according to GHS). There was an adverse local effect on the skin [2]. Upon dimethylammonium chloride intake $\mathrm{LK}_{50}$ is $70 \mathrm{mg} / \mathrm{m}^{3}$ (Category 2 according to GHS).

In the process of information retrieval, it was found that the substance is not volatile, its vapor pressure is $<1 \times 10^{-2} \mathrm{~Pa}$ at $20^{\circ} \mathrm{C}$, at $50^{\circ} \mathrm{C}$ it is $2,3 \times 10^{-4} \mathrm{~Pa}$ (US ISC); it has high surface activity and is sprayed only in large drops of MMAD $>40 \mu \mathrm{m}$ size [2, 3]. DDAC $(80 \%)$ has marked irritant effect on the rabbits' skin and conjunctiva (Category 1 in accordance with GHS) causing burns (corrosion) [1-10]. No sensitizing effect of the compound on guinea pigs was revealed by Magnusson and Kligman method while performing skin tests (not classified according to GHS) [1-10]. The cumulative properties of the substance are not significant [2-10]. Noobserved effect levels for DDAC were determined in subacute experiment after oral, dermal and inhalation exposure [2-16]. When the substance was administered to rats through the gastrointestinal tract for 28 days NOAELwas $2.5 \mathrm{mg} / \mathrm{kg}$. During a 90-day oral toxicity study, it was estimated that NOAEL for rats is $46 \mathrm{mg} / \mathrm{kg}$ of body weight per day. Taking technical DDAC (80.8\%) with fodder at doses of $0,30,60$ and $90 \mathrm{mg} / \mathrm{kg}$ during the period of 21 days caused in Beagle dogs impaired gastrointestinal function, and weight loss. NOEL for dogs is $60 \mathrm{mg} / \mathrm{kg}$.

Under the conditions of subchronic exposure, the NOEL was slightly lower. It was 
found that NOEL for dogs was $15 \mathrm{mg} / \mathrm{kg}$ when they took DDAC for 90 days with fodder. Taking DDAC with fodder by CD-1 mice on a daily basis for 90 days at doses of 100, 300, 600 1000 , and $3000 \mathrm{ppm}$ caused a decrease in body weight and death of animals. NOEL for mice was determined at $600 \mathrm{ppm}$.

High doses of technical preparation $(80.8 \%)$ which was administered through gastric catheter to Beagle dogs for 8 weeks (doses of $7.5,15,30$ and $60 \mathrm{mg} / \mathrm{kg}$ ) caused their death, symptoms of intoxication and defecatory disorder. There was a lot of mucus in their fecal masses. NOAEL $-7.5 \mathrm{mg} / \mathrm{kg}$. When $0.6 \%$ aqueous solution of DDAC was applied to skin for 5 days, its NOAEL was $2.5 \mathrm{mg} / \mathrm{kg}$. The same NOAEL value was when a compound in the form of $0.3 \%$ aqueous solution was applied to skin for 2 weeks.

Swelling, erythema, epidermitis, dermatitis, spot hemorrhage, vascular degeneration and skin ulcers were observed in Sprague-Dawley rats whose skin surface was exposed to DDAC aqueous solution in amounts of 2,6 and $12 \mathrm{mg} / \mathrm{kg}$ for 13 weeks (6 hours exposure, 5 times a week).

After 90-day application of the preparation to the skin, NOAEL for systemic toxicity was $12 \mathrm{mg} / \mathrm{kg} /$ day, and NOAEL for local effect was $2 \mathrm{mg} / \mathrm{kg} /$ day.

Studies have been conducted to determine the DDAC toxicity when administered to the organism as aerosol through the respiratory system of Sprague-Dawley rats in concentrations of $0.15 \pm 0.15 \mathrm{mg} / \mathrm{m}^{3}, 0.58 \pm 0.40 \mathrm{mg} / \mathrm{m}^{3}$, $3.63 \pm 1,56 \mathrm{mg} / \mathrm{m}^{3}$ for 2 weeks. The mass median aerodynamic diameter of DDAC aerosols was $1.86 \mu \mathrm{m}$, and the geometric standard deviation was $2.75 \mu \mathrm{m}$. In groups exposed to high concentrations, a decrease in body weight of $2.6 \mathrm{~g}$ was observed, whereas in the control group an increase of $25.8 \mathrm{~g}$ after the first 3 days was observed. There were no changes in hematological and biochemical parameters of blood. There were slight changes in the amount of differentiation of bronchoalveolar cells and cell damage in the fluid of bronchoalveolar contents in groups of animals which were exposed to the preparation in high and medium concentrations. Although infiltration of inflammatory cells of interstitial pneumonia was partially observed, fibrosis in the lungs was not detected when exposed to medium and high concentrations. DDAC
NOAEL for rats was determined as $0.15 \mathrm{mg} / \mathrm{m}^{3}$ $[11,12]$.

The inhalation toxicity of DDAC aerosol was studied in Sprague-Dawley rats in chambers for 13 weeks at concentrations of 0.11 , 0.36 , and $1.41 \mathrm{mg} / \mathrm{m}^{3}$ The mass median aerodynamic diameters of the aerosol were $0.63 \mu \mathrm{m}$, $0.81 \mu \mathrm{m}$, and $1.65 \mu \mathrm{m}$, while the geometric standard deviations were $1.62,1.65$, and 1.65 in groups with low $\left(0.11 \pm 0,06 \mathrm{mg} / \mathrm{m}^{3}\right)$, mid $\left(0,36 \pm 0,20 \mathrm{mg} / \mathrm{m}^{3}\right)$ and high $\left(1,41 \pm 0,71 \mathrm{mg} / \mathrm{m}^{3}\right)$ concentrations of exposure respectively. The average body weight of males was $35 \%$ lower while that of females $15 \%$ lower in the high concentration group $\left(1.41 \pm 0.71 \mathrm{mg} / \mathrm{m}^{3}\right)$ compared to the control group. While testing the fluid of bronchoalveolar lavage, it was found that the amount of albumin and lactate dehydrogenase was within the normal range. Infiltration of inflammatory cells and interstitial pneumonia, as well as lung weight increase were observed at exposures to mid and high concentrations of DDAC. However, no serious histopathological disorders in the lungs, including proteinosis and/or fibrosis, have been identified. Based on the results of changes in body weight and lungs, NOAEL for rats was defined as $0.11 \mathrm{mg} / \mathrm{m}^{3}$ [13].

The study of the DDAC toxicity properties in a chronic experiment was performed on three species of animals: rats, mice and dogs [2 $10,15]$. Sprague-Dawley CD rats took the technical preparation $(80.8 \%)$ with fodder for 104 weeks at doses of 300, 750 and $1500 \mathrm{ppm}$. Decrease in body weight and feed intake, as well as pathology of mesenteric lymph nodes (hemosiderosis and histiocytosis, blood in the sinuses) were noted at $1500 \mathrm{ppm}$ exposure dose of DDAC. DDAC NOEL for rats in general toxicity terms is $750 \mathrm{ppm}(27 \mathrm{mg} / \mathrm{kg})$.

CD-1 mice took technical DDAC $(80.8 \%)$ with fodder for 18 months in amounts of 100 , 500 and $1000 \mathrm{ppm}$. A decrease in body weight and feed intake were observed in animals at 1000 ppm. NOEL for male and female mice in terms of systemic toxicity was defined as $500 \mathrm{ppm}$.

Clinical symptoms of intoxication (hypersalivation, vomiting, abnormal fecal masses), weight loss, periodical albumin, total protein and cholesterol decreased levels in blood serum, as well as erythrocytes, hemoglobin and hematocrit drop in peripheral blood were observed in Beagle dogs which were exposed to DDAC through catheter in the amount of 3,10 


\section{ORIGINAL RESEARCH \\ TOXICOLOGY OF PESTICIDES}

or $30 \mathrm{mg} / \mathrm{kg}$ per day during the period of 1 year. DDAC NOAEL for dogs in terms of systemic toxicity was defined as $10 \mathrm{mg} / \mathrm{kg}$, in terms of local reaction $-3 \mathrm{mg} / \mathrm{kg}$.

The carcinogenic properties of DDAC have been explored in 3 animal species: rats, mice and dogs. Sprague-Dawley CD rats received the substance with fodder at doses of 300,750, and 1500 ppm for 104 weeks. CD-1 mice were given the preparation with fodder in the amount of 100, 500 and 1000 ppm for 18 months. Beagle dogs received the substance through gastric catheter in the amount of 3,10 or $30 \mathrm{mg} / \mathrm{kg}$ per day for 1 year. No carcinogenic effect was detected: NOAEL after chronic DDAC exposure was $32-41 \mathrm{mg} / \mathrm{kg}$ per day for rats, 76$93 \mathrm{mg} / \mathrm{kg}$ per day for mice, and $10 \mathrm{mg} / \mathrm{kg}$ per day for dogs.

The mutagenic effect of DDAC was not detected either in vitro or in vivo tests (Ames test, with or without microsomal activation / fraction S-9 / on Salmonella typhimurium; in Chinese hamster ovary cells, in rats hepatocytes of unplanned DNA synthesis, induction of chromosomal aberrations in mouse bone marrow cells and induction of micronuclei in mouse bone marrow cells).

No negative effect of DDAC (80.8\%) on the reproductive function of Sprague-Dawley rats (CD) in the two generations test was found. The animals received the substance with fodder at doses of 10, 30 and $52 \mathrm{mg} / \mathrm{kg}$. Cortical adrenal hypertrophy was observed at the maximum dose in females of the Fo generation. A decrease in body weight and an increase in spleen mass was observed in the F1 generation. No change in reproductive function was recorded. DDAC NOEL in terms of systemic toxicity was determined as $32 \mathrm{mg} / \mathrm{kg}$ [15].

When introduced through catheter into the CDBR Sprague-Dawley rats which were 6 to15 days pregnant (doses 1, 12.5 25, 37.5, and $50 \mathrm{mg} / \mathrm{kg})$, DDAC (80.8\%, solvent - Millipore deionized water) in higher doses caused respiratory malfunctions (polypnoea, dyspnoea) and decreased feed intake. There was an increase in post-implantation mortality, a decrease in fetal body weight at a dose of $50 \mathrm{mg} / \mathrm{kg}$. NOAEL for the maternal rats was $12.5 \mathrm{mg} / \mathrm{kg}$, for the fetus - $37.5 \mathrm{mg} / \mathrm{kg}$. According to other authors, NOAEL for females in terms of systemic toxicity was $1.0 \mathrm{mg} / \mathrm{kg}$ [2]. When the preparation was administered to 6 to 15 days pregnant rabbits in high doses (12 and $32 \mathrm{mg} / \mathrm{kg}$ ), symptoms of intoxication and abortions were observed. NOAEL for pregnant female rabbits was $4 \mathrm{mg} / \mathrm{kg}$, for fetuses $-12 \mathrm{mg} / \mathrm{kg} \mathrm{[2,3]}$.

DDAC is a highly ionic compound. Studies in rats proved that $85-90 \%$ of the preparation is excreted within 24 hours through the gastrointestinal system, and $2.6-3 \%$ - through the urinary system. In animal tissues, less than $1 \%$ of the substance is found. DDAC metabolism by intestinal microflora results in the formation of hydroxylation products of an alkyl chain and involves the oxidation of 2 decyl side chains in the form of derivatives of hydroxyand hydroxyketone compounds. In the body of females, the metabolism of the substance is faster than in males.

Approximately $0.1 \%$ of the dose of DDAC aqueous solution penetrates the skin when tested for 24 hours in human cells culture (in vitro). The amount of radioactive substance in the dermis and epidermis was $9.41 \%$ of the dose applied to the skin.

Thus, analysis of the bibliographic data about DDAC toxic properties proved that DDAC produces a marked irritant effect on the skin and conjunctiva. The substance belongs to moderately toxic substances in intragastric action while it is low toxic at dermal exposure. It does not have sensitizing or cumulative properties. Mutagenic, carcinogenic, embryo toxic, teratogenic effects and toxic effect on reproductive function are not limiting harmful criteria.

The calculation of DDAC ISEL in the workplace air was performed using the equations that take into account the parameters of toxicity of the preparation depending upon different routes of its intake by laboratory animals, in accordance with the "Methodological Guidelines for Establishing Indicative Safe Exposure Levels of Harmful Substances in the Workplace Air" ("Metodicheskih ukazanij po ustanovleniju orientirovochnyh bezopasnyh urovnej vozdejstvija vrednyh veshhestv v vozduhe rabochej zony") (P. 4000-85 from 04.X1.1985) and the formulas given in the section "Substantiation for Indicative Safe Exposure Levels (ISEL) of Pesticides in the Workplace Air When They are Used in Agriculture" of Methodological Guidelines for Hygienic Evaluation of New Pesticides, Kyiv, 1988 ("Obosnovanie orientirovochnyh bezopasnyh urovnej vozdejstvija (OBUV) pes- 


\section{ORIGINAL RESEARCH \\ TOXICOLOGY OF PESTICIDES}

ticidov v vozduhe rabochej zony pri ih primenenii v sel'skom hozjajstve" (Metodicheskie ukazanija po gigienicheskoj ocenke novyh pesticidov, Kiev, 1988) [2, 3].

The formulas by which the calculation of DDAC ISEL in the workplace air was performed are given in Table 1.

The parameters in the formula were calculated in accordance with the following data: $\operatorname{Lim}_{\mathrm{ch}}$ was derived from the equation: $\lg \mathrm{Lim}_{\mathrm{ch}}$ $\left(\mathrm{mg} / \mathrm{m}^{3}\right)=0.62 \times \lg \mathrm{CL}_{50}\left(\mathrm{mg} / \mathrm{m}^{3}\right)-1.08$.

The figures given in the formula were calculated according to the following data: $\operatorname{Lim}_{\mathrm{ch}}$ $\left(\mathrm{mg} / \mathrm{m}^{3}\right)=0,62 \times \lg 70-1,08=0,07 \mathrm{Lim}_{\mathrm{ch}}=$ $1,17 \mathrm{mg} / \mathrm{m}^{3}$

$\mathrm{SF}$ is a relationship between $\mathrm{CL}_{50} / \mathrm{Limch}$ and Css (species sensitivity coefficient) in accordance with MU (Recommended Practices) No. 1599-77,

Where CL50 is $70 \mathrm{mg} / \mathrm{m}^{3}$

$\mathrm{CL}_{50} /$ Limch $=59.83-$ corresponds to 3 points,

Css $=1.0-$ correspondsto 2 points

$\mathrm{SF}=3 \times 2=6$

According to the calculations, the value of ISEL is at $0.195 \mathrm{mg} / \mathrm{m}^{3}$. was determined by the equation: $\lg \operatorname{Lim}_{\mathrm{ch}}$

As can be seen from the above data, the value of DDAC ISEL in the workplace air is calculated by different formulas and ranges from 0.195 to $0.47 \mathrm{mg} / \mathrm{m}^{3}$. The arithmetic mean of the presented ISEL values is $0.276 \mathrm{mg} / \mathrm{m}^{3}$, the ISEL geometric mean is $0.246 \mathrm{mg} / \mathrm{m}^{3}$. Recommended DDAC ISEL in the workplace air is $0.2 \mathrm{mg} / \mathrm{m}^{3}$, aggregate state "a", marked "protection of eyes and skin is necessary". The mass concentration of DDAC in the workplace air is determined by the photometric method (the range of quantitative determination of concentrations from $0.1 \mathrm{mg} / \mathrm{m}^{3}$ to $1.0 \mathrm{mg} / \mathrm{m}^{3}$ ).

\section{Conclusions}

1. Based on DDAC toxicity parameters under different conditions of laboratory animals' exposure to the substance, it belongs to Category 1 substances in accordance with GHS.

2. The DDAC limiting harmful criteria are its marked irritant effect on the skin and conjunctiva, as well as acute inhalation action.

3. The recommended DDAC ISEL in the workplace air is $0.2 \mathrm{mg} / \mathrm{m}^{3}$, aggregate state "a", marked "protection of eyes and skin is necessary”.

Table 1

Formulas for calculating DDAC ISEL

\begin{tabular}{|c|c|}
\hline Equation & ISEL $\mathrm{mg} / \mathrm{m}^{3}$ \\
\hline 1. ISEL $=0.002 \times \mathrm{LD}_{50}$ per os & 0.47 \\
\hline 2. $\lg \mathrm{ISEL}=0.58 \lg \mathrm{LD}_{50}$ per os -1.96 & 0.26 \\
\hline 3. $\lg \mathrm{ISEL}=0.47 \operatorname{lgLD} \mathrm{D}_{50}$ per os $+0.11 \operatorname{lgLD}_{50}$ derm - 2.02 & 0.36 \\
\hline 4. $\lg \mathrm{ISEL}=0.52 \operatorname{lgLD} 50$ per os $+0.04 \operatorname{lgLD} \mathrm{D}_{50}$ derm +0.04 Ccum -2.13 & 0.2 \\
\hline 5. $0.467 \operatorname{lgLD}_{50}$ per os $+0.06 \operatorname{lgLD} 50$ derm +0.04 Ccum -2.12 & 0.25 \\
\hline 6. $Y=\exp \left(0.58 \ln L D_{50}\right.$ per os -4.51$)$ & 0.26 \\
\hline 7. $Y=\exp \left(0.47 \ln L D_{50}\right.$ per os $+0.11 \ln L D_{50}$ derm - 4.66 & 0.30 \\
\hline 8. $\mathrm{Y}=\exp \left(0.52 \operatorname{lnLD} \mathrm{D}_{50}\right.$ per os +0.1 Ccum -4.9 & 0.21 \\
\hline 9. $Y=\exp \left(0.46 \ln L d_{50}\right.$ per os $+0.06 \operatorname{lnLD_{50}}$ derm +0.1 Ccum - 4.87) & 0.26 \\
\hline $\begin{array}{ll}\text { Where: } & \mathrm{LD}_{50} \text { per os }=238 \mathrm{mg} / \mathrm{kg} \\
& \mathrm{LD}_{50} \text { derm }=3342 \mathrm{mg} / \mathrm{kg} \\
& \text { Ccum }>5\end{array}$ & \\
\hline
\end{tabular}

The calculation of DDAC ISEL in the workplace air was performed using a formula for organic substances which have general toxic effect:

10. ISEL = estimated Limch/ SF (SF - safety factor). 


\section{ORIGINAL RESEARCH \\ TOXICOLOGY OF PESTICIDES}

The autors declare that there are no conflicts of interest.

\section{REFERENCES}

1. Registered Data Dossier. Helsinki, Finland: European Chemicals Agency. Available at: http://echa.europa.eu/ search-chemicals

2. Directive 98/8/EC Concerning the Placing of Biocidal Products on the Market. The Inclusion of Active Substances in Annex I to Directive 98/8/EC. Italy, June 2015. URL: http://dissemination.echa.europa.eu/Biocides/ Active Substances/0067-08/0067-08_Assessment_Report.pdf

3. Didecyldimethylammonium Chloride. Europa EU. URL: http://dissemination.echa.europa.eu/Biocides/ActiveSubsta nces/0067-08/0067-08_Assessment_Report.pdf.

4. Electronic resource. URL: http://www.regulations.gov/

5. US National Institute of Medicine. National Center for Biotechnology Information. Compound summary. Didecyl Dimethyl Ammonium. URL: https://pubchem. ncbi.nlm.nih.gov/compound/didecyl_dimethyl_ammonium chloridesection=Top.

6. Electronic resource. - URL: https://pubchem.ncbi. nlm.nih.gov/ compound/ddidecyl_dimethyl_ammonium chloride\#section=acute-Effects.

7. The toxicity data was from the legacy RTECS data set in ChemIDplus. Electronic resource, URL: https://chem.nlm.nih.gov/chemidplus/sid/ 0007173515.

8. Biocide Didecyldimethyl Ammonium Chloride, DDAC. Didecyl Dimethyl Ammonium Chloride SDS MSDS Sheet. URL: http://finoric.com/msdssheet/ddacbiocidedidecyldimethylammonium chloride.htm.

9. Didecyldimethylammoniumchloride. California Environmental Protection Agency. URL: http://www.cdpr.ca.gov/ docs/risk/toxsums/toxsumlist.htm.

10. Toxicol Research - 2017. - Jan 33(1) - P. 7-14. doi: 10.5487/ TR.2017.33.1.007. Epub, 2017. Jan. 15. URL: https://www.ncbi.nlm.Nihgov/pubmed/28133508

11. Kim Y. S., Lee S. B. (2017). Didecyldimethylammonium Chloride (DDAC) is used in many types of biocidal products including tableware, carpets, humidifiers, and swimming pools, etc. In spite of increased chances of DDAC exposure through inhalation, inhalation studies on the toxicity of DDAC. Toxicol Research, - Vol. 33. - №1. - P. $7-$ 14. URL: https: //www. ncbi. nlm.nih.gov /pubmed/ 25343015

12. Ohnuma A. (2010) Didecyldimethylammonium chloride induces pulmonary inflammation and fibrosis in mice. Experimental and Toxicologic Pathology, - Vol. 62. №6. - P 643-51.

13. Kim Y. S., Lee S. B., Lim C. H. (2017). Effects of Didecyldimethylammonium Chloride (DDAC) on SpragueDawley Rats after 13 Weeks of Inhalation Exposure. Toxicol Research, Jan; 33(1), - P. 7-14. URL: https://www.ncbi.nlm.nih.gov/pubmed/28133508.

14. Jung-Taek Kwon, Hyun-Mi Kim, Pilje Kim \& Kyunghee Choi (2014). Didecyldimethylammonium chloride induces oxidative stress and inhibits cell growth in lung epithelial cells. Molecular and Cellular Toxicology - Vol. 10 - №1, P. 41-45. URL: https://link.springer.com/article/10.1007/ s13273-014-0005-z.

15. Didecyldimethylammonium Chloride. Electronic resource. URL: http://www.cdpr.ca.gov/docs/risk/toxsums/toxsumlist.htm.

16. Dezinficirujushhie sredstva bez hlora. Djul'bak DTBL. [Chlorine-free disinfectants. Dyulbak DTBL].

17. Instrukcija № 002/1 po primeneniju sredstva dezinficirujushhego s mojushhim effektom TEJJA-2 na predprijatijah pishhevoj i pererabatyvajushhej promyshlennosti [Instruction №002/1 for the application of TEYA-2 disinfectant with a washing effect at food-producing and processing enterprises]. Moscow, 2018, 13 p. (in Russian).

18. Stepan S. Safety data sheet. BTC $1010-80 \%$. URL: http://echa.europa.eu/search-chemicals.

19. Pasport Bezopasnosti. Dezinficirujushhee sredstvo Wetrok SintoCleanHN [Safety Data Sheet. Disinfectant Wetrok SintoCleanHN]. URL: http://echa.europa.eu/search-chemicals.

20. Safety Data Sheet. Parhem. Didecyl Dimethyl Ammonium Chloride. URL: http://echa.europa.eu/search-chemicals.

21. Safety Data Sheet. Disinfectant DSC Fopte Desifoam AQ/ DR. SCHNELL GMBHF \& CO. KgaA. URL: http://echa.europa.eu/search-chemicals.

22. Maklakov A. S. (2009). Preparat na osnove chetvertichnyh ammonievyh soedinenij dlja dezinfekcii obektov veterinarnogo nadzora. [The preparation on the basis of quaternary ammonium compounds for disinfection of objects of veterinary supervision]. (Phd Thesis), Moscow. URL: http://medical-diss.com/veterinariya/ preparation-onbasics-hetver-tichnyh-ammonievyh-soedineniy-dlya-disinfectant-objects-veterinary-control №ixzz5oAzbQy87 (in Russian).

23. Popov N. I. Maklakov A. S. (2008). Toksikologicheskaja harakteristika preparata Smejk ${ }^{\circledR}$ [Toxicological characteristics of Smejk ${ }^{\circledR}$ preparation]. Veterinarija [Veterinary Medicine], Moscow - №4, - P. 50-54. URL: http://medical-diss.com/ veterinary / preparation-on-basics-hetvertichnyh-ammonievyh-soedineniy-dlya-disinfectionobjects-veterinary-control №ixzz5oAzbQy87 (in Russian).

24. Metodicheskiie ukazaniia po ustanovleniiu oriientirovochnyh bezopasnyh urovnei vozdeistviia v vozduhe rabochei zony [Methodological guidelines for establishing indicative safe levels of exposure to harmful substances in the workplace air], Moscow, 1985, 19 p. (in Russian).

25. VNIIGINTOKS (1988). Metodicheskie Ukazanija po Gigienicheskoj Ocenke Novyh Pesticidov [Methodological Guidelines for Hygienic Evaluation of New Pesticides], Kyiv. - P 36-39 (in Russian). 


\section{ТОКСИКОЛОГІЧНЕ ОБГРУНТУВАННЯ ГІГІЕНІЧНОГО НОРМАТИВУ ДИДЕЦИЛДИМЕТИЛАМОНІЙ ХЛОРИДУ У ПОВІТРІ РОБОЧОЇ ЗОНИ}

П.Г. Жмінько, В.М. Вороніна, С.С. Світлий, Л.О. Рудая

ДП «Науковий центр превентивної токсикології, харчової та хімічної безпеки імені академіка Л.І.Медведя Міністерства охорони здоров'я України» м.Київ, Україна

PEЗЮМЕ. Вступ. Дидецилдиметиламоній хлорид (DDAC) використовується в якості сировини в хімічній промисловості при виробництві деяких інсектицидних, фунгіщидних, альдегідних препаратів і дезинфікуючих засобів як діюча речовина. Мета досліджень. На основі аналізу та узагальнення даних літературі щодо ступеня небезпечності DDAC науково обгрунтувати його орієнтовно-безпечний рівень впливу (ОБРВ) у повітрі робочої зони.

Матеріали і методи. Для обгрунтування гігієнічного нормативу DDAC у повітрі робочої зони аналізували його фізико-

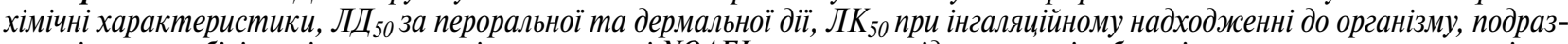
нюючі та сенсибілізуючі властивості, встановлені NOAEL речовини в підгострому і субхронічному екпериментах за різних шляхів надходження до організму, віддалені ефекти.

Розрахунок величини ОБРВ DDAC у повітрі робочої зони проведено за рівняннями, які враховують параметри токсичності препарату за різних шляхів надходження до організму лабораторних тварин.

Результати. DDAC - імпортована продукція, використовується як діюча речовина при виробництві деяких пестицидних та дезинфікуючих засобів.

DDAC відноситься до нелетких речовин: тиск парів $<1 \times 10^{-2}$ Па при $20^{\circ} \mathrm{C}$, при $50^{\circ} \mathrm{C}-2,3 \times 10^{-4}$ Па (US ISC).

При введенні в шлунково-кишковий канал він класифікований як помірно небезпечний - 3 категорія (згідно з Globally Harmonized System of Classification and Labeling of Chemicals /GHS/ United Nations, New York and Geneva, 2017), володіє cлабовираженою шкірно-резорбтивною дією (4 категорія, GHS). Виявлено його несприятливий місцевий вплив на шкіру. ЛК50 речови-

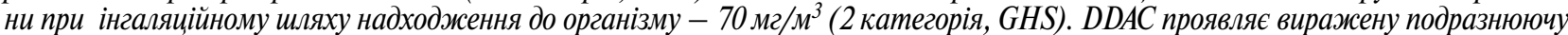
дію на шкіру і слизові оболонки очей кролів (1B категорія, GHS). На шкірі відмічали появу еритеми, струпи, набряк. Опіки, корозію, гострий кератокон'юнктивіт спостерігали при потраплянні на слизові оболонки очей. Не виявлено сенсибілізуючої дії препарату (не класифікується, GHS). Кумулятивні властивості речовини не виражені. Встановлені NOAEL у підгострому i субхронічному експериментах при пероральному, дермальному та інгаляційному шляхах надходження до організму. Найбільш уражені органи та системи - шкіра, очі, шлунково-кишковий тракт, печінка. Мутагенний, канцерогенний, ембріотоксичний, тератогенний ефекти та токсична дія на репродуктивну функцію не є лімітуючими критеріями шкідливості речовини.

Розрахунок величини ОБРВ DDAC у повітрі робочої зони проведено за рівняннями регресійної залежності, що враховують параметри гострої токсичності. Беручи до уваги ступінь його небезпеки, ризик розвитку патології загального генезу за дії

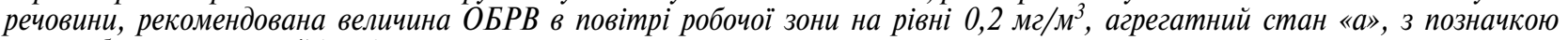
«потребує захисту очей і шкіри».

Ключові слова: дидецилдиметиламоній хлорид, DDAС, ОБРВ у повітрі робочої зони, інсектициди, дезінфікуючі засоби.

\section{ТОКСИКОЛОГИЧЕСКОЕ ОБОСНОВАНИЕ ГИГИЕНИЧЕСКОГО НОРМАТИВА ДИДЕЦИЛДИМЕТИЛАММОНИЯ ХЛОРИДА В ВОЗДУХЕ РАБОЧЕЙ ЗОНЫ}

П.Г. Жминько, В.М. Воронина, С.С. Светлый, Л.А. Рудая

ГП «Научный иентр превентивной токсикологии, пищевой и химической безопасности имени академика Л.И. Медведя Министерства здравоохранения Украины», г. Киев, Украина

PЕЗЮМЕ. Введение. Дидецилдиметиламмоний хлорид (DDAC) используется в качестве сырья в химической промышленности при производстве некоторых инсектицидных, фунгицидных, альдегидних препаратов и дезинфицирующих средств в качестве действующего вещества.

Цель исследований. На основе анализа и обобщения данных литературы о степени опасности DDАС научно обосновать его ориентировочно безопасный уровень воздействия (ОБУВ) в воздухе рабочей зоны.

Материалы и методы. Для обоснования гигиенического норматива DDAC в воздухе рабочей зоны анализировали его физико-химические свойства и токсикологическую характеристику (ЛД ${ }_{50}$ при пероральном и дермальном действии, ЛК ингаляционном поступлении в организм, раздражающие и сенсибилизирующие свойства, NOAEL вещества в подостром и субхроническом и хроническом экспериментах при различных путях поступления в организм, отдаленные эффекты).

Расчет величины ОБУВ DDАС в воздухе рабочей зоны проведен по уравнениям регрессионной зависимости, которые учитывают параметры токсичности препарата при различных путях поступления в организм лабораторных животных.

Результаты. DDAC - импортированная продукции, используемая в качестве действующего вещества при производстве некоторых пестицидных и дезинфищирующих средств. DDAC относится к нелетучих веществам. Давление пара $<1 \times 10^{-2}$ Па при $20{ }^{\circ} \mathrm{C}$, при $50^{\circ} \mathrm{C}-2,3 \times 10^{-4}$ Па (US ISC). При введении в желудочно-кишечный канал он классифицирован как умеренно опасный - 3 категория (согласно Globally Harmonized System of Classification and Labeling of Chemicals / GHS / United Nations, New York and Genеva, 2017), обладает слабовыраженным кожно-резорбтивным действием (4 категория, GHS). Выявлено его неблагоприятное

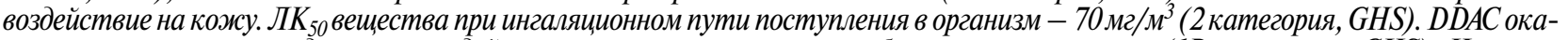
зывает выраженное раздражающее действие на кожу и слизистые оболочки глаз кроликов (1В категория, GHS). Ha коже отмечали появление эритемы, струпья, отек. Ожоги, коррозию, острый кератоконбюнктивит наблюдали при поступлении $D D A C$ на слизистые оболочки глаз. Не выявлено сенсибилизирующего действия (не классифицирован, GHS). Кумулятивные свойства вещества не выражены. Установлены NOAEL в подостром и субхроническом эксперименте при пероральном, дермальном и ингаляционном путях поступления в организм. Наиболее чувствительные органы и системы кожка, глаза, желудочно-кишечный тракт, печень. Мутагенный, канцерогенный, эмбриотоксический, тератогенный эффекты и токсическое действие на репродуктивную функцию не являются лимитирующими критериями вредности вещества.

Расчет величины ОБУВ DDAС в воздухе рабочей зоны проведено по уравнениям регрессионной зависимости, учитывающих параметры острой токсичности. Принимая во внимание степень его опасности, риск развития патологии общего генеза

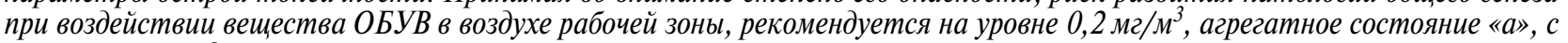
пометкой «нуждается в защите глаз и кожи».

Ключевые слова: дидецилдиметиламмоний хлорид, DDAC, ОБУВ в воздухе рабочей зоны, инсектицидные средства, дезинфицирующие средства.

Received 02/27/2020 